\title{
OBITUARY
}

\section{REINHOLD PALMQVIST}

Dr Palmovist who died on ro February I940 was born in Stockholm on I9 April I885 and educated at the University in that city. He was the actuary at the Inspecting Board for Private Insurance from 1915 to 1917 and actuary to the Thule Insurance Company from 1918. He was well known to English actuaries owing to the prominent part he took in connexion with the Swedish Society of Actuaries and with the International Congresses, and we shall all remember him as one of the secretaries of the successful Congress in Stockholm. He wrote several papers on mathematical, actuarial and insurance subjects, the last being a joint paper with Dr Hagstroem on fluctuation of interest for the Paris Congress which he attended, although the illness that clouded the last few years of his life had then begun. Though Palmqvist's own work was well known and admired, he deserves a special niche in actuarial fame for his chief editorship of Skandinavisk Aktuarietidskrift during a period of nearly twenty years, and the continuous excellence of that fournal is a high tribute to his ability as editor. English actuaries will remember Palmqvist not only with gratitude for the good work he did for our profession but as a good friend and a pleasant companion.

W. P. E.

WILLIAM A. ROBERTSON, F.F.A., F.R.S.E.

By the death of William A. Robertson shortly before his Presidency of the Faculty of Actuaries had run the full course, the Faculty suffered a most grievous loss. There was no actuary in Edinburgh better known or better loved by his colleagues, and though he was seldom seen at the Institute here in London there were many London men who had the privilege of counting him among their friends. When his Presidency of the Faculty brought him into closer touch with men of the Institute, that circle of friends was enlarged and the ties of the Faculty and the Institute became still more closely knit.

He had a yet wider circle, for there were actuaries in every Englishspeaking country who owed him a debt of gratitude for the assistance he gave them in preparation for their examinations: He had been an ideal coach, and every student of his remembered him not only as tutor but as a friend-one might go further and say that to all those who had the benefit of his tuition he was an elder brother and never ceased to be 
a brother. How much this was borne out when, during the visit of a party of British actuaries to America, Robertson's name was mentioned! How he would have enjoyed a personal meeting with many who had to be content to send a message by mutual friends! He was so enthusiastic, so full of life, that one was never dull in his company, and no doubt it was this buoyant spirit which infected his students and gave them constant encouragement in their efforts. His enthusiasm was not confined to his professional work; it found equal scope in his play and he had the same reputation in a wide circle of football devotees as he had amongst his professional friends.

Edinburgh is the poorer without him and his city pays its own tribute to him; in London and the world over, wherever his students are found, there will long remain memories of that cheery elder brother, whom, as they all grew older together, they called "Willie Robertson".

H. J. P. $O$.

\section{On Active Service}

John Denton Hargreaves, Probationer, Gunner, Royal Air Force. Killed in air crash in France, 4 April 1940.

Killed by Enemy Action

William Elder Gillett, Fellow, 2 October 1940.

Arthur Frank Wainwright, Student, 26 October 1940. 